\title{
Evidence for a Role of Opioid Peptides in the Release of Arginine Vasopressin in the Conscious Rat
}

\author{
SAN-E ISHIKAWA and RoBERT W. SCHRIER, Department of Medicine, University of \\ Colorado Health Sciences Center, Denver, Colorado 80262
}

A BSTRACT Recent reports have suggested that opioid peptides may be involved in renal water excretion. The present in vivo experiments, therefore, were undertaken to determine the effect of opioid peptides on the osmotic and nonosmotic release of arginine vasopressin (AVP) in the conscious rat. Experimental animals were infused intravenously with naloxone $(20 \mu \mathrm{g} / \mathrm{kg}$ per $\mathrm{min})$ or oxilorphan $(40 \mu \mathrm{g} / \mathrm{kg}$ per $\mathrm{min})$, chemically dissimilar opioid antagonists. Control rats were infused with normal saline, the vehicle for the opioid antagonists. In all three groups the osmotic release of AVP was examined during an acute hypertonic saline (3\%) infusion $(2 \mathrm{ml} / 100 \mathrm{~g}$ body $\mathrm{wt})$. The antidiuresis following the hypertonic saline infusion was significantly attenuated in naloxone- and oxilorphan-treated rats, as the peak urinary osmolality (Uosm) rose to $581.4 \pm 22.4$ and $558.2 \pm 27.6 \mathrm{mosmol} /$ $\mathrm{kg} \mathrm{H}_{2} \mathrm{O}$ in naloxone- and oxilorphan-treated rats as compared with the value in control rats of $735.3 \pm 24.2$ $\mathrm{mosmol} / \mathrm{kg} \mathrm{H}_{2} \mathrm{O}$ (both $P<0.001$ vs. control). At the same time the plasma AVP levels of $5.4 \pm 1.3$ and $5.2 \pm 1.1 \mathrm{pg} / \mathrm{ml}$ in naloxone- and oxilorphan-treated rats, respectively, were significantly lower than the plasma AVP in control rats of $16.9 \pm 2.5 \mathrm{pg} / \mathrm{ml}(P$ $<0.001)$. In another three groups of rats the nonosmotic release of AVP was examined during hypovolemia induced by intraperitoneal $6 \%$ dextran $(1.8 \mathrm{ml} /$ $100 \mathrm{~g}$ body wt). Following intraperitoneal administration of dextran the peak Uosm of $703.0 \pm 87.8$ and $734.8 \pm 99.1 \mathrm{mosmol} / \mathrm{kg} \mathrm{H}_{2} \mathrm{O}$ in naloxone- and oxilorphan-treated rats, respectively, was significantly less than the value in control rats of $1,169.3 \pm 135.5$ $\mathrm{mosmol} / \mathrm{kg} \mathrm{H}_{2} \mathrm{O}$ (both $P<0.02$ vs. control). A comparable decrease in blood volume of $13 \%$ occurred in all three groups of animals. During the dextran administration plasma AVP levels in naloxone- and oxilorphan-treated rats increased to $4.3 \pm 1.0$ and $6.0 \pm 2.0$ $\mathrm{pg} / \mathrm{ml}$, respectively; both of these values were signif-

Address reprint requests to Dr. Schrier.

Received for publication 17 July 1981 and in revised form 26 October 1981. icantly lower than the plasma AVP of $12.9 \pm 1.4 \mathrm{pg} / \mathrm{ml}$ in control rats $(P<0.02)$. The effect of opioid antagonists to impair the osmotic and nonosmotic release of AVP occurred in the absence of differences in mean arterial pressure, glomerular filtration rate and the renal response to AVP. These results, therefore, indicate that opioid peptides are involved in renal water excretion primarily by modulating the central release of AVP.

\section{INTRODUCTION}

Opioid peptides are derived from a common precursor, $\beta$-lipotropin (1), and the genetic sequencing of opioid peptides is determined by the sequence of ACTH- $\beta$-lipotropin $(2,3)$. These opioid peptides are distributed in various tissues that originated from ectoderm; thus, the hypothalamus and pituitary gland are areas of high opioid content as measured by radioimmunoassay techniques (4). The opioid peptides are divided into two groups, namely the endorphins and enkephalins. In the pituitary gland the endorphins are localized mainly in the adenohypophysis and pars intermedia, while the enkephalins are localized mainly in the neurohypophysis. Since there are also opioid receptors with high affinity binding properties in the neurohypophysis (5), it is reasonable to suggest that enkephalins may be involved in the release of arginine vasopressin (AVP) ${ }^{1}$ from the neurohypophysis.

The first study that examined the antidiuretic effect of morphine was reported by DeBodo in 1944 (6) and, more recently, several additional studies have reexamined the role of opiates and opiate antagonists (6$11)$ and opioid peptides (12-17) in renal water excretion. Taken together, these studies have not yielded consistent results. Specifically, opiates and opioid peptides have been suggested both to stimulate $(6-13,17)$ and to inhibit AVP release (14-16). The purpose of the

\footnotetext{
${ }^{1}$ Abbreviations used in this paper: AVP, arginine vasopressin; Hct, hematocrit; MAP, mean arterial pressure; Posm, plasma osmolality; Uosm, urinary osmolality.
} 
present experiments was to determine whether endogenous opioid peptides are important in the osmotic and nonosmotic release of AVP. The results of these experiments revealed that two different opioid antagonists, namely naloxone and oxilorphan, significantly attenuated both the osmotic and nonosmotic release of AVP in the conscious rat. These results therefore support an influence of opioid peptides on the central release of AVP.

\section{METHODS}

Studies were performed on male Sprague-Dawley rats weighing $250-300 \mathrm{~g}$. The rats were allowed free access to food and water until the time of the experiments. After ether anesthesia, the rats underwent placement of external jugular venous and carotid arterial catheters (PE-50, Clay-Adams, Div., Beckton, Dickinson \& Co., Parsippany, N. J.) as well as a suprapubic polyethylene bladder catheter (PE-100, Clay Adams). The animals were then placed in a restrainer (Narco Biosystems, Inc., Houston, Tex.) and allowed to awaken. At least $30 \mathrm{~min}$ then were allowed before experiments were started.

Hypertonic saline protocol. To achieve a water diuresis the animals were infused with $0.3 \%$ saline containing inulin $(1.2 \mathrm{~g} / 100 \mathrm{ml}$ ) at a rate of $6 \mathrm{ml} / \mathrm{h}$ (model 355, Sage Instruments Div., Orion Research Inc., Cambridge, Mass.). After a volume of hypotonic saline equivalent to $2-3 \%$ of body wt had been administered the majority of rats had a urinary osmolality (Uosm) of $150 \mathrm{mosmol} / \mathrm{kg} \mathrm{H}_{2} \mathrm{O}$ ) or below. Only those rats with a Uosm in this hypotonic range were used in the present experiments. After a stable water diuresis was established, three 5-min control urine collections were obtained for the measurement of urine volume, Uosm, and inulin concentration. At $15 \mathrm{~min}$, a $0.5-\mathrm{ml}$ blood sample was taken for the measurement of hematocrit (Hct), plasma osmolality (Posm), and inulin concentration.

After this control period, the experimental rats were infused with one of two opioid antagonists, naloxone hydrochloride $(20 \mu \mathrm{g} / \mathrm{kg}$ per min, Endo Laboratories Co., Garden City, N. Y.) or oxilorphan tartrate $(40 \mu \mathrm{g} / \mathrm{kg}$ per min, Bristol Laboratories Co., Syracuse, N. Y.), at a rate of $2 \mathrm{ml} / \mathrm{h}$. The control group of rats were infused at the same infusion rate with $0.9 \%$ saline, the vehicle for the opioid antagonists. The infusions of opioid antagonists or the vehicle were continued throughout the remainder of the experiment. $30 \mathrm{~min}$ after the start of the infusion of opioid antagonists or the vehicle, three 5-min urine collections and a 0.5 -ml blood sample were obtained for the measurement of urine volume, Uosm, and urinary inulin concentration, and Hct, Posm, and plasma inulin concentration, respectively. After these collections, the response to an osmotic stimulus was tested with an infusion of $3 \% \mathrm{NaCl}(2.0 \mathrm{ml} / 100 \mathrm{~g}$ body $\mathrm{wt})$ administered over a 4-5-min period. After completing the hypertonic infusion, urine samples were collected at 5-min intervals and $0.2-\mathrm{ml}$ blood samples were taken at 15 -min intervals for $90 \mathrm{~min}$. The blood samples were replaced with an equivalent volume of isotonic saline.

Another group of equally treated experimental and control rats received the hypertonic saline and had plasma AVP concentrations measured. Since the peak Uosm after the infusion of hypertonic saline was found to occur between 18 and $23 \mathrm{~min}$ in our earlier experiments $(18)$, a $2.0-\mathrm{ml}$ blood sample was taken rapidly over $10 \mathrm{~s}$ through the carotid artery catheter exactly $20 \mathrm{~min}$ after commencing the infusion of hypertonic saline. The water-diuresing rats were prepared in the same manner as all other animals. In these animals plasma AVP samples were drawn after a water diuresis was established (Uosm $<150 \mathrm{mosmol} / \mathrm{kg} \mathrm{H}_{2} \mathrm{O}$ ). We have previously established that blood removal over $10 \mathrm{~s}$ does not stimulate AVP release rapidly enough to effect the AVP content in the withdrawn blood specimen (18).

Hyperoncotic dextran protocol. The intraperitoneal administration of $6 \%$ of dextran T-70 (Pharmacia Fine Chemicals, Inc., Piscataway, N. J.) was used as a nonosmotic, hypovolemic stimulus for AVP release. Rats used in this experiment were prepared in the same manner as described above, with the exception of placement of an intraperitoneal catheter (PE-350, Clay-Adams) at the time of surgery. After establishing a water diuresis, control collections of blood and urine samples were obtained, followed by the infusion of naloxone, oxilorphan or the vehicle as described in the hypertonic saline protocol. The animals were then given an intraperitoneal injection of dextran $(1.8 \mathrm{ml} / 100 \mathrm{~g}$ body $\mathrm{wt})$ at a rate of $1 \mathrm{ml} / \mathrm{min}$. The estimated oncotic pressure of this solution (van't Hoff equation) is $800 \mathrm{~mm} \mathrm{H}_{2} \mathrm{O}$. After injection of intraperitoneal dextran, the experimental periods were started and urine was collected at 5-min intervals and blood was taken every $15 \mathrm{~min}$ for $90 \mathrm{~min}$. The blood removed was replaced with an equivalent volume of isotonic saline. Estimated changes in blood volume $(\Delta \mathrm{BV})$ were calculated by the formula $[\Delta \mathrm{BV}=1-($ Het $2 /$ Het 1$)]$. This method probably underestimates the $\triangle \mathrm{BV}$ because it does not account for the erythrocyte volume removed during blood sampling.

In a separate group of experimental and control rats, blood samples were taken for the determination of AVP. Because the peak Uosm after the injection of dextran was found to occur between 30 and $60 \mathrm{~min}$ in our earlier experiments, $2.0-\mathrm{ml}$ blood samples were taken rapidly over $10 \mathrm{~s}$ through the carotid arterial line exactly $45 \mathrm{~min}$ after the start of the experimental periods.

Studies on the effect of opioid antagonists on the renal response to exogenous $A V P$. To ascertain whether any of the observed changes in Uosm in rats receiving opioid antagonists was due to an alteration in the renal response to $A V P$, the responses to exogenous AVP were examined. The rats were prepared in the same manner as noted in the previous protocols. After establishing a water diuresis, three 4min urine collections were obtained. Immediately after these collections, a bolus of $4 \mathrm{ng} / \mathrm{kg}$ body wt of AVP (Aqueous Pitressin; Parke-Davis \& Co., Detroit, Mich.) was administered. Sequential 4-min urine collections were taken until Uosm returned to $150 \mathrm{mosmol} / \mathrm{kg} \mathrm{H}_{2} \mathrm{O}$ or below. At this time naloxone, oxilorphan, or the vehicle was administered at the same rates as in earlier protocols. $45 \mathrm{~min}$ later three 4-min control urine collections were again obtained, and then a second bolus of $4 \mathrm{ng} / \mathrm{kg}$ body wt of AVP was administered. Again, urine collections were continued until Uosm decreased to $<150 \mathrm{mosmol} / \mathrm{kg} \mathrm{H}_{2} \mathrm{O}$.

In all studies arterial blood pressure was monitored throughout the experiments by a strain gauge (Statham Transducers, Statham Instruments Div., Gould Inc., Oxnard, Calif.; and model 7702B, Hewlett-Packard Co., Palo Alto, Calif.). Hct was measured by Micro Hematocrit Tube Reader, model CR (International Equipment Co., Div. Damon Corp., Needham Heights, Mass.), Posm by vapor pressure osmometer (Wescor Inc., Logan, Utah), and Uosm by freezing-point depression (model 3R, Advanced Instruments, Inc., Needham Heights, Mass.). The vapor pressure osmometer correlates within $1 \%$ of the value recorded by both freezing-point depression and calculated osmolality (19). Inulin 
concentrations were measured by autoanalyzer (Technicon Instruments Corp., Tarrytown, N. Y.)

AVP measurements. All blood samples for the measurement of AVP were withdrawn into heparinized syringes, and then transferred to glass tubes on ice. These samples were centrifuged at $4^{\circ} \mathrm{C}$ at $2,000 \mathrm{rpm}$ (model PR-J, International Equipment Co.) for $10 \mathrm{~min}$. The plasma was then removed and frozen at $-20^{\circ} \mathrm{C}$ until the specimens were thawed and AVP measured. These samples were extracted by the method of Robertson et al. (20). The acetone extracts were prepared by mixing $1.0 \mathrm{ml}$ of plasma with $2.0 \mathrm{ml}$ of cold acetone. After centrifugation at $3,000 \mathrm{rpm}$ for $20 \mathrm{~min}$, the supernate was decanted from the precipitate, thoroughly mixed with $4.0 \mathrm{ml}$ of cold ether, and centrifuged again. After centrifugation the upper layer was carefully aspirated and discarded. The acetone remaining in the lower aqueous phase was eliminated under a stream of room air. The precipitations were then dissolved in $0.5 \mathrm{ml}$ of phosphate-buffered saline and AVP measurements determined by radioimmunoassay (21).

The lower limit of AVP detection on the standard curves is $0.5 \mathrm{pg} / \mathrm{ml}$. A synthetic AVP (Ferring Co., Malmo, Sweden; $400 \mathrm{U} / \mathrm{mg}$ ) was used for the standard curves. Intra- and interassay coefficients of variation are 14.0 and $13.7 \%$, respectively. Oxytocin cross-reacted by $<0.1 \%$ with the AVP antiserum, while lysine vasopressin showed $10 \%$ immunoreactivity when compared with AVP (21).

Statistics. In each rat mean Uosm, Posm, mean arterial pressure (MAP), Hct, and inulin clearance, at the time of the peak Uosm and Uosm V after the administration of 3\% $\mathrm{NaCl}$ or $6 \%$ dextran were compared to their mean values during control periods of the same rats by the paired Student's $t$ test. These same parameters as well as plasma levels of AVP were also compared between control and experimental groups of rats by the unpaired Student's $t$ test. A $P$ value of $<0.05$ was considered significant.

\section{RESULTS}

Hypertonic saline study. The Posm during the water diuresis and after administration of opioid antagonists or the vehicle ranged from 287.0 to 291.2 mosmol $/ \mathrm{kg} \mathrm{H}_{2} \mathrm{O}$ and was not significantly different among the three groups. The Posm after intravenous administration of hypertonic saline increased significantly by $\sim 20 \mathrm{mosmol} / \mathrm{kg} \mathrm{H}_{2} \mathrm{O}$ in all of the three groups of animals $(P<0.001)$. In all three groups the Uosm during the water diuresis was $<150 \mathrm{mosmol} / \mathrm{kg}$ $\mathrm{H}_{2} \mathrm{O}$ as shown in Fig. 1. After the administration of the opioid antagonists or the vehicle Uosm remained $<150 \mathrm{mosmol} / \mathrm{kg} \mathrm{H}_{2} \mathrm{O}$. After the infusion of $3 \%$ saline the peak Uosm was signficantly less in the naloxoneand the oxilorphan-treated rats as compared with the control rats. Specifically, peak Usom rose to $581.4 \pm 22.4$ $(n=7)$ and $558.2 \pm 27.6 \mathrm{mosmol} / \mathrm{kg} \mathrm{H} \mathrm{H}_{2} \mathrm{O}(n=7)$ in naloxone- and oxilorphan-treated rats, respectively, and these values were significantly lower than the Uosm in control rats $(n=7)$ of $735.2 \pm 24.2 \mathrm{mosmol} /$ $\mathrm{kg} \mathrm{H}_{2} \mathrm{O}(P<0.001)$ (Fig. 1). As depicted in Table I, MAP, Hct, and inulin clearance were not significantly different among the three groups of animals during

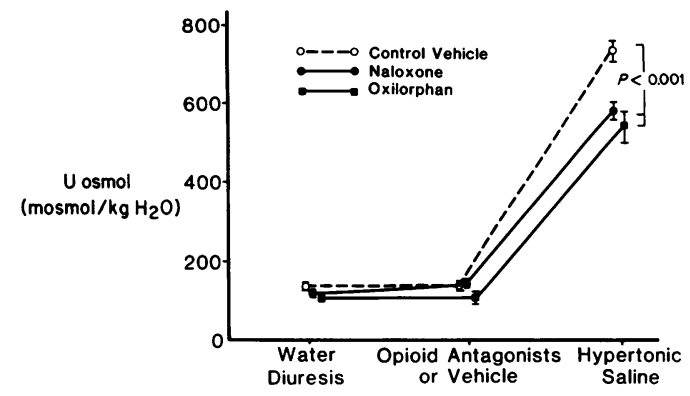

Figure 1 Effect of opioid antagonists to blunt the response of peak Uosm to hypertonic saline infusion. Values indicate mean $\pm \operatorname{SEM}(n=7)$.

any phase of the experiments. There were no significant differences in UosmV among the three groups during control periods and after the infusion of hypertonic saline.

The results of Posm and plasma AVP levels are shown in Fig. 2. Mean plasma AVP level during the water diuresis was $0.5 \pm 0.2 \mathrm{pg} / \mathrm{ml}(n=7)$. In all three groups the plasma AVP levels after the infusion of hypertonic saline were significantly higher than the plasma AVP levels during water diuresis $(P<0.005)$. Plasma AVP concentrations were $5.4 \pm 1.3 \mathrm{pg} / \mathrm{ml}$ in the naloxone-treated rats $(n=9), 5.2 \pm 1.1 \mathrm{pg} / \mathrm{ml}$ in the oxilorphan-treated rats $(n=7)$, and $16.9 \pm 2.5 \mathrm{pg} / \mathrm{ml}$ in control rats $(n=10)$. The increase in plasma AVP in both naloxone- and oxilorphan-treated rats after the infusion of hypertonic saline was significantly less than the AVP concentrations in the control rats (both $P$ $<0.001$ ).

Hyperoncotic dextran study. Comparable decreases in blood volume $(\sim 13 \%)$ occurred in all three groups of rats following the intraperitoneal administration of dextran $(P<0.001)$. As depicted in Fig. 3, Uosm during water diuresis was $<150 \mathrm{mosmol} / \mathrm{kg} \mathrm{H}_{2} \mathrm{O}$ in all three groups of rats, and remained $<150$ mos$\mathrm{mol} / \mathrm{kg} \mathrm{H}_{2} \mathrm{O}$ after the administration of opioid antagonists or the vehicle. Following the administration of dextran all animals had an antidiuresis in response to the decrease in blood volume. However, the peak Uosm responses in rats receiving opioid antagonists were signficantly blunted when compared to rats receiving vehicle alone (Fig. 3). Peak Uosm rose to $703.0 \pm 87.8(n=8)$ and $734.8 \pm 99.1 \mathrm{mosmol} / \mathrm{kg} \mathrm{H}_{2} \mathrm{O}$ $(n=8)$ in naloxone- and oxilorphan-treated rats, respectively, values that were significantly lower than the control value of $1,169.3 \pm 135.5 \mathrm{mosmol} / \mathrm{kg} \mathrm{H} \mathrm{H}_{2} \mathrm{O}$ $(n=8)$ (both $P<0.02$ vs. control). MAP was slightly but significantly decreased in all three groups of rats after the intraperitoneal administration of dextran (Table II). Posm and inulin clearance were not significantly different among the three groups of animals 
TABLE I

Profile of Changes in MAP, Inulin Clearance $\left(C_{I n}\right)$, and Hct in the Presence or Absence of Opioid Antagonists in the Hypertonic Saline Experiments

\begin{tabular}{|c|c|c|c|c|c|c|c|c|c|}
\hline & \multicolumn{3}{|c|}{ Control $(n=7)$} & \multicolumn{3}{|c|}{ Naloxone $(n=7)$} & \multicolumn{3}{|c|}{ Oxilorphan $(n=7)$} \\
\hline & Control & Vehicle & Saline & Control & Naloxone & Saline & Control & Oxilorphan & Saline \\
\hline \multirow{2}{*}{$\begin{array}{c}\text { MAP, } m m ~ H g \\
\text { Mean } \pm \text { SE } \\
P \text { value }\end{array}$} & $117.3 \pm 2.4$ & $117.1 \pm 2.4$ & $118.0 \pm 2.3$ & $113.1 \pm 3.4$ & $114.7 \pm 3.3$ & $113.0 \pm 3.4$ & $113.0 \pm 2.7$ & $113.3 \pm 2.9$ & $112.0 \pm 2.1$ \\
\hline & NS & $\mathbf{N}$ & & NS & $\mathbf{N}$ & & Ns & $\mathrm{N}$ & \\
\hline \multicolumn{10}{|l|}{$\mathrm{C}_{\mathrm{In}}, m l / \min$} \\
\hline $\begin{array}{l}\text { Mean } \pm \text { SE } \\
P \text { value }\end{array}$ & $\begin{array}{r}3.2 \pm 0.1 \\
\mathrm{NS}\end{array}$ & $\begin{array}{r}3.2 \pm 0.1 \\
\mathrm{~N}\end{array}$ & $S \quad 3.2 \pm 0.1$ & $\begin{array}{r}3.1 \pm 0.2 \\
\mathrm{NS}\end{array}$ & $\begin{array}{lr}2.8 \pm 0.2 \\
S\end{array}$ & S & $\begin{array}{r}3.0 \pm 0.2 \\
\mathrm{~N}\end{array}$ & S & $2.9 \pm 0.3$ \\
\hline \multicolumn{10}{|l|}{ Het, \% } \\
\hline $\begin{array}{l}\text { Mean } \pm S E \\
P \text { value }\end{array}$ & $\begin{array}{r}37.6 \pm 0.7 \\
\text { NS }\end{array}$ & $\begin{array}{r}38.5 \pm 0.7 \\
\mathrm{~N}\end{array}$ & $S \quad 38.5 \pm 0.8$ & $\begin{array}{r}38.6 \pm 0.6 \\
\text { NS }\end{array}$ & $S \quad 38.2 \pm 0.5$ & $S$ & $\begin{array}{r}37.3 \pm 0.8 \\
\mathrm{~N}\end{array}$ & $S$ & $37.2 \pm 0.9$ \\
\hline
\end{tabular}

during any phase of the experiment (Table II). Uosm V was not signficantly different among the three groups of animals during control periods and after the intraperitoneal administration of dextran.

In Fig. 4 are shown the results of decrements in blood volume and plasma AVP levels in the hyperoncotic dextran studies. Plasma AVP levels during water diuresis were $0.6 \pm 0.2 \mathrm{pg} / \mathrm{ml}(n=7)$, and $45 \mathrm{~min}$ after the intraperitoneal dextran administration plasma AVP levels were significantly increased in all the three groups of rats $(P<0.01)$. The plasma AVP levels were $4.3 \pm 1.0 \mathrm{pg} / \mathrm{ml}$ in the naloxone-treated rats $(n=9)$, $6.0 \pm 2.0 \mathrm{pg} / \mathrm{ml}$ in the oxilorphan-treated rats $(n=7)$, and $12.9 \pm 1.4 \mathrm{pg} / \mathrm{ml}$ in the control rats $(n=7)$. During hyperoncotic dextran administration the values of plasma AVP in both naloxone- and oxilorphan-treated rats were significantly lower than the values in the control group receiving the vehicle $(P<0.001$ and $P$ $<0.02$, respectively).

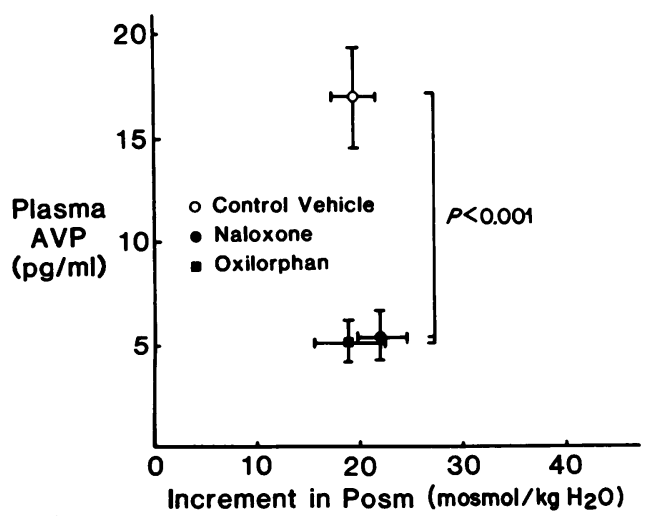

FIGURE 2 Effect of opioid antagonists to blunt the plasma AVP response to an osmotic stimulation with hypertonic saline. Values indicate mean $\pm S E M$.
Effect of opioid antagonists on the renal response to exogenous AVP. In the control group of rats ( $n$ $=6$ ), Uosm was increased from $112.3 \pm 3.3$ to $510.8 \pm 27.0$ mosmol $/ \mathrm{kg} \mathrm{H}_{2} \mathrm{O}(P<0.001)$ by the first bolus of AVP, and then decreased to $133.0 \pm 2.9 \mathrm{mosmol} / \mathrm{kg} \mathrm{H}_{2} \mathrm{O}(P$ $<0.001$ ). During vehicle administration Uosm was increased from $134.3 \pm 11.1$ to $533.0 \pm 31.3 \mathrm{mosmol} / \mathrm{kg}$ $\mathrm{H}_{2} \mathrm{O}(P<0.001)$ by the second bolus of AVP, which then decreased to $130.3 \pm 8.3 \mathrm{mosmol} / \mathrm{kg} \quad \mathrm{H}_{2} \mathrm{O}$ ( $P$ $<0.001)$. In the naloxone group of rats $(n=6)$, the first bolus of AVP increased Uosm from 115.8 \pm 10.2 to $579.6 \pm 78.8 \mathrm{mosmol} / \mathrm{kg} \mathrm{H}_{2} \mathrm{O}(P<0.001)$, and Uosm

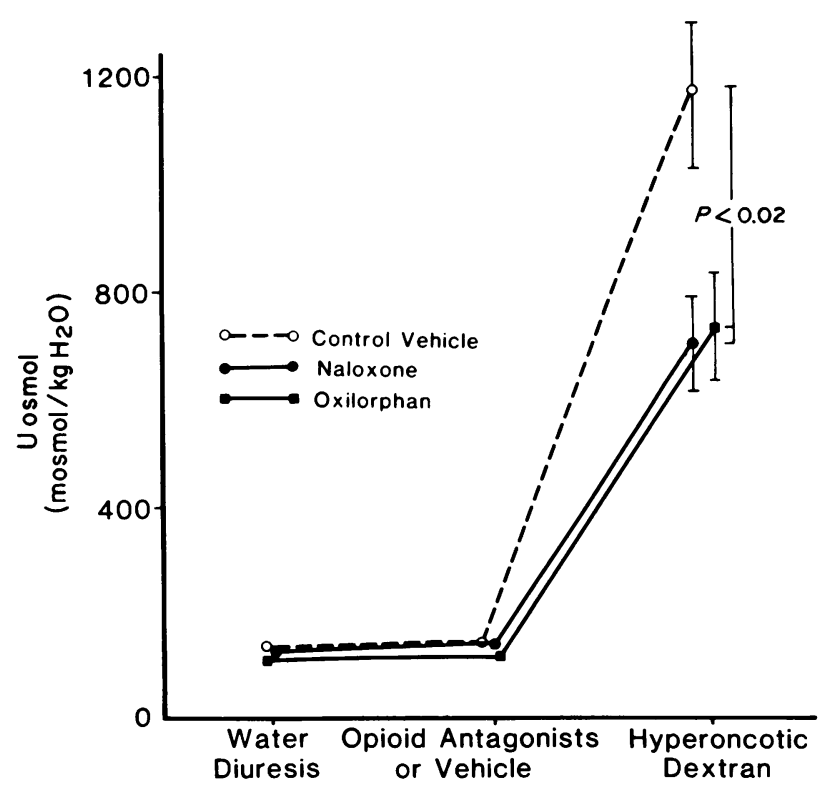

FIGURE 3 Effect of opioid antagonists to blunt the response of peak Uosm to the intraperitoneal administration of $6 \%$ dextran. Values indicate mean $\pm \operatorname{SEM}(n=8)$. 
TABLE II

Profile of Changes in MAP, Inulin Clearance $\left(C_{I n}\right)$, and Posm in the Presence or Absence of Opioid Antagonists in the Hyperoncotic Dextran Study

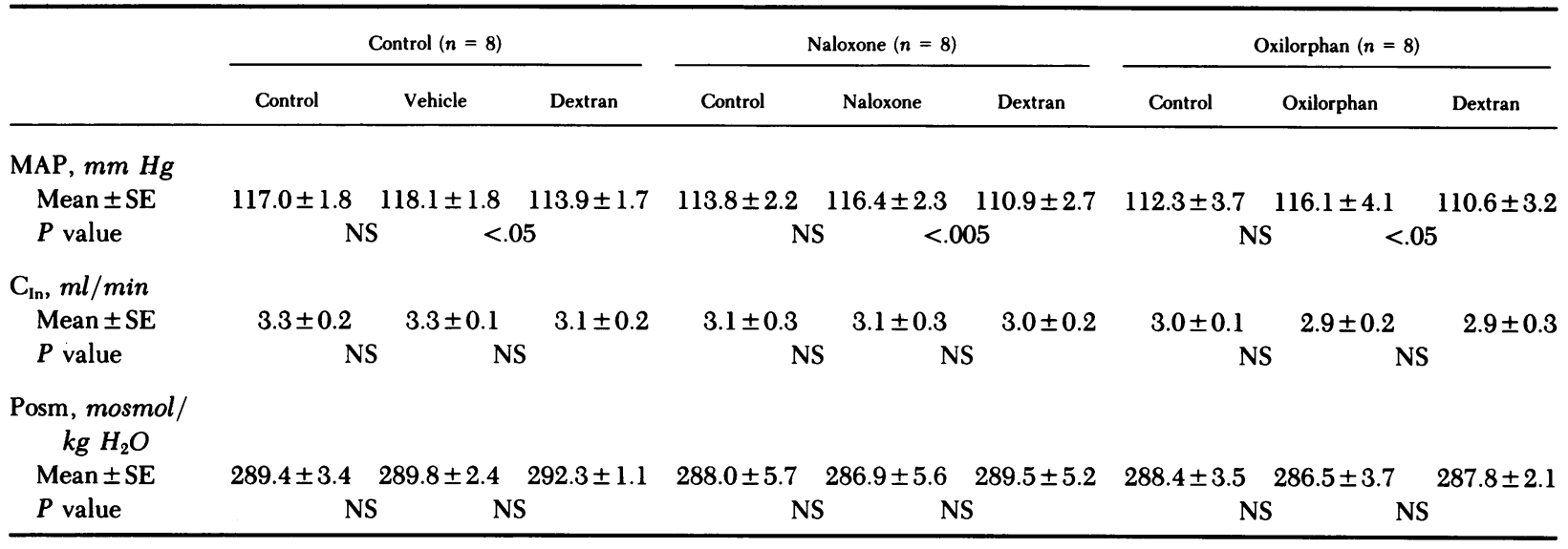

returned to $123.2 \pm 12.9 \mathrm{mosmol} / \mathrm{kg} \mathrm{H} \mathrm{H}_{2} \mathrm{O}(P<0.001)$ after the effect of the hormone dissipated. After naloxone administration, Uosm was $127.0 \pm 12.7 \mathrm{mosmol} /$ $\mathrm{kg} \mathrm{H}_{2} \mathrm{O}$ and the second bolus of AVP increased Uosm to $554.8 \pm 45.4 \mathrm{mosmol} / \mathrm{kg} \mathrm{H}_{2} \mathrm{O}(P<0.001)$, which then decreased to $141.3 \pm 4.6 \mathrm{mosmol} / \mathrm{kg} \mathrm{H}_{2} \mathrm{O}(P<0.001)$. In the oxilorphan group of rats $(n=6)$, Uosm increased from $108.2 \pm 15.5$ to $504.0 \pm 76.4 \mathrm{mosmol} / \mathrm{kg} \mathrm{H}_{2} \mathrm{O}(P$ $<0.001$ ) after the first bolus of AVP and then fell to $123.3 \pm 9.0 \mathrm{mosmol} / \mathrm{kg} \mathrm{H} \mathrm{H}_{2} \mathrm{O}(P<0.001)$. After oxilorphan administration a second bolus of AVP increased Uosm from $120.8 \pm 8.6$ to $510.5 \pm 55.2 \mathrm{mosmol} / \mathrm{kg} \mathrm{H} \mathrm{H}_{2} \mathrm{O}$ $(P<0.001)$, which then returned to $142.3 \pm 5.0$ mos$\mathrm{mol} / \mathrm{kg} \mathrm{H}_{2} \mathrm{O}(P<0.001)$. In all three groups of rats the response of peak Uosm to exogenous AVP was not significantly different during any phase of the experiments. Similar studies were performed using $1 \mathrm{ng} / \mathrm{kg}$ rather than $4 \mathrm{ng} / \mathrm{kg}$ of AVP. Once again no end-organ effect of opioid antagonist on the renal response to

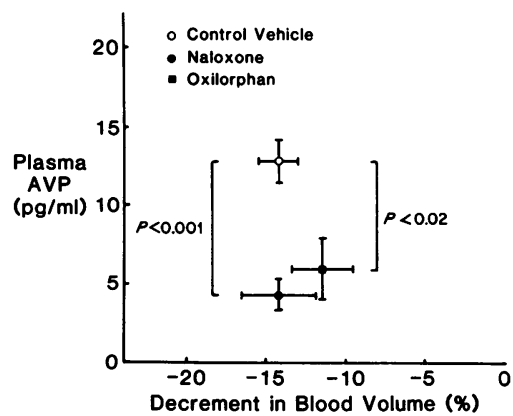

Figure 4 Effect of opioid antagonists to blunt the response of plasma AVP to decrements in blood volume during the intraperitoneal administration of $6 \%$ dextran. Values indicate mean $\pm S E M$.
AVP was observed. Thus, at the doses of opioid antagonists used in the present study there was no evidence for an effect on the renal response to AVP.

\section{DISCUSSION}

Recent studies using immunocytochemical techniques $(22,23)$ have demonstrated that enkephalin-containing neurons are interspersed between AVP- and oxytocincontaining neurons in the supraoptic and paraventricular nuclei of the rat hypothalamus. The axon terminals of these enkephalin-containing neurons have been observed to extend into the neurohypophysis. Similar results were found in the preoptic nucleus of the goldfish $(24,25)$. These anatomical results suggested that opioid peptides might be involved in the release of AVP. Moreover, recent evidence indicates the presence of high-affinity opioid receptors in the bovine neurohypophysis (5). Preliminary studies by Rossier et al. $(22,23)$ have provided some physiological support for the role of opioid peptides in AVP release. These investigators found parallel decreases in the neurohypophyseal content of leucine-enkephalin and AVP after $24 \mathrm{~h}$ of fluid deprivation in the rat. Recent studies in man have also suggested that opioid antagonists may alter the osmotic threshold of AVP release (26) as well as impair the nonosmotic release of AVP during tilting (27). Opioid peptides might, therefore, be expected to stimulate AVP release and yet both in rat $(15,28)$ and man $(16)$ they have been reported to inhibit AVP release. Some of these variations in results could relate to renal or extrarenal effects of opioid peptides or antagonists independent of any central effect on AVP release, as well as differences in the specific mode of stimulating AVP release.

In the present study the effect of opioid antagonists 
on the osmotic (hypertonic saline) and nonosmotic (intraperitoneal dextran) release of AVP was further examined and blood pressure and glomerular filtration rate also were monitored. The present studies were performed in conscious water-diuresing rats since the use of anesthesia in such studies could lead to difficulties in interpretation. Also, since the opioid antagonists may have additional effects, it seemed important to perform the present experiments with two chemically dissimilar antagonists. The results of the present experiments demonstrated that both osmotic and nonosmotic release of AVP were significantly impaired by prior administration of either naloxone or oxilorphan. This impaired release of AVP was associated with the expected diminution in the rise in Uosm during both the osmotic and nonosmotic stimuli. This diminished antidiuresis was associated with a normal end-organ response to maximal and submaximal doses of exogenous AVP. Moreover, the absence of differences in MAP and glomerular filtration rate among the three groups of animals during all experiments did not support intrarenal alterations as an explanation for the difference in urinary concentration. Huidobro and Huidobro-Toro (10), however, have shown that morphine has a direct effect on the kidney. In the present study the opioid antagonists did not alter the renal response to exogenous AVP. Thus, impaired AVP release was primarily responsible for the diminished peak Uosm during both osmotic and nonosmotic stimuli in the naloxone- and oxilorphan-treated animals as compared with the control (vehicle) rats. These differences in AVP release occurred in spite of a comparable rise in Posm $\left(\sim 20 \mathrm{mosmol} / \mathrm{kg} \mathrm{H}_{2} \mathrm{O}\right)$, i.e., osmotic stimulus, and fall in blood volume $(\sim 13 \%)$, i.e., nonosmotic stimulus, in all groups of animals.

Naloxone and oxilorphan produced virtually identical effects. Since naloxone is considered to be an essentially pure narcotic antagonist, while oxilorphan has both agonist and antagonist properties $(9,29)$, the results in the present study provide evidence that the inhibitory effect of the two drugs on AVP release is a consequence of their narcotic antagonist properties rather than agonist activity, as suggested by other investigators (26). The present results, however, are not in concert with other findings that did not demonstrate an effect of naloxone on osmotically mediated AVP release $(28,30)$. There is no ready explanation for these latter differences. It should be emphasized, however, that the present studies were performed in conscious rats, using a sensitive radioimmunoassay for AVP, two chemically dissimilar opioid antagonists and both osmotic and nonosmotic release of AVP were examined.

Since the nonosmotic (baroreceptor) pathway (31) and osmoreceptors (32) are known to reside outside of the blood-brain barrier, an effect of intravenous opioid antagonists on these two anatomically separate pathways (33) for AVP release is certainly tenable $(26,27)$. However, since opioid antagonists are known to penetrate the blood-brain barrier readily (34), their intravenous effect on AVP release could reside at the level of the paraventricular and supraoptic nuclei in the hypothalamus. Recent investigations $(10,11,13)$ in which intracerebroventricular administrations of opiate or opioid peptides caused an increase in AVP release support this possibility and are quite compatible with the present results. As already mentioned, enkephalin-containing neurons have been demonstrated to be interspersed among AVP- and oxytocin-containing neurons in the hypothalamus, thus making the paraventricular and supraoptic nuclei a likely site of action of the opioid antagonists. Since the axons of enkephalinergic neurons terminate in the neurohypophysis, an effect of the opioid antagonists at the level of the neurohypophysis is also possible, particularly since opioid receptor binding has been found in the neurohypophysis (5).

In summary, the present in vivo results demonstrate that two chemically dissimilar opioid antagonists impair urinary concentration in the conscious rat by diminishing the osmotic and nonosmotic release of AVP from the hypothalamo-neurohypophyseal tract. This impairment is demonstrable in the absence of differences in MAP, glomerular filtration rate, solute excretion, and the renal response to AVP.

\section{ACKNOWLEDGMENTS}

We wish to thank Ms. Linda M. Benson for secretarial assistance.

This work was supported by National Institutes of Health Program Project grant AM 19928 and National Institutes of Health training grant AM 07135.

\section{REFERENCES}

1. Rossier, J., and F. E. Bloom. 1979. The central neuropharmacology of endorphins. Adv. Biochem. Psychopharmacol. 20: 165-185.

2. Nakanishi, S., A. Inoue, T. Kita, M. Nakamura, A. C. Y. Chang, S. N. Cohen, and S. Numa. 1979. Nucleotide sequence of cloned cDNA for bovine corticotropin- $\beta$ lipotropin precursor. Nature (Lond.). 278: 423-427.

3. Nakanishi, S., Y. Teranishi, M. Noda, M. Natake, Y. Watanabe, H. Kakidani, H. Jingami, and S. Numa. 1980. The protein-coding sequence of bovine ACTH- $\beta$-LPH precursor gene is split near the signal peptide region. Nature (Lond.). 287: 752-755.

4. Rossier, J., T. M. Vargo, S. Minick, N. Ling, F. E. Bloom, and $R$. Guillemin. 1977. Regional dissociation of $\beta$-endorphin and enkephalin contents in rat brain and pituitary. Proc. Natl. Acad. Sci. U. S. A. 74: 5162-5165.

5. Simantov, R., and S. H. Snyder. 1977. Opiate receptor binding in the pituitary gland. Brain Res. 124: 178-184.

6. DeBodo, R. C. 1944. The antidiuretic action of morphine and its mechanism. J. Pharmacol. Exp. Ther. 82: 74-85. 
7. Schneider, H., and E. K. Blackmore. 1955. The effect of nalorphine on the antidiuretic action of morphine in rats and men. Br. J. Pharmacol. 10: 45-50.

8. Inturrisi, C. E., and J. M. Fujimoto. 1968. Studies on the antidiuretic action of morphine in the rat. Eur. J. Pharmacol. 2: 301-307.

9. Miller, M. 1975. Inhibition of $\mathrm{ADH}$ release in the rat by narcotic antagonists. Neuroendocrinology. 19: 241-251.

10. Huidobro, F., and J. P. Huidobro-Toro. 1979. Antidiuretic effect of morphine and vasopressin in morphine tolerant and nontolerant rats, differential effects on urine composition. Eur. J. Pharmacol. 59: 55-64.

11. Aziz, L. A., M. L. Forsling, and C. J. Woolf. 1981. The effect of intracerebroventricular injections of morphine on vasopressin release in the rat. J. Physiol. (Lond.). 311: 401-409.

12. Weitzman, R. E., D. A. Fisher, S. Minick, N. Ling, and R. Guillemin. 1977. $\beta$-Endorphin stimulates secretion of arginine vasopressin in vivo. Endocrinology. 101: 16431646.

13. Bisset, G. W., H. S. Chowdrey, and W. Feldberg. 1978. Release of vasopressin by enkephalin. Br. J. Pharmacol. 62: 370-371.

14. Meuhlethaler, M., B. H., Gaehwiler, and J. J. Dreifuss. 1980. Enkephalin-induced inhibition of hypothalamic paraventricular neurons. Brain Res. 197: 264-268.

15. Iversen, L. L., S. D. Iversen, and F. E. Bloom. 1980. Opiate receptors influence vasopressin release from nerve terminals in rat neurohypophysis. Nature (Lond.). 284: $350-351$

16. Grossman, A., G. M. Besser, J. J. Milles, and P. H. Baylis. 1980. Inhbition of vasopressin release in man by an opiate peptide. Lancet. II: 1108-1110.

17. Baertschi, A. J., H. H. Zingg, and J. J. Dreifuss. 1981. Enkephalins, substance $P$, bradykinin and angiotensin II: differential sites of action on the hypothalamo-neurohypophyseal system. Brain Res. 220: 107-119.

18. Miller, T. R., W. A. Handelman, P. E. Arnold, K. M. McDonald, P. B. Molinoff, and R. W. Schrier. 1979. Effect of central catecholamine depletion on the osmotic and nonosmotic stimulation of vasopressin in the rat. $J$. Clin. Invest. 64: 1599-1607.

19. Kopp, J. 1975. Osmolality study. Med. Electron Data. July-Aug: 66-72.

20. Robertson, G. L., E. A. Mahr, S. Athar, and T. Sinha. 1973. Development and clinical application of a new method for the radioimmunoassay of arginine vasopressin in human plasma. J. Clin Invest. 52: 2340-2352.

21. Anderson, R. J., P. G. Pluss, A. S. Berns, J. T. Jackson, P. E. Arnold, R. W. Schrier, and K. M. McDonald. 1978. Mechanism of hypoxia on renal water excretion. J. Clin. Invest. 62: 769-777.
22. Rossier, J., E. Battenberg, Q. Pittman, A. Bayon, L. Koda, R. Miller, R. Guillemin, and F. Bloom. 1979. Hypothalamic enkephalin neurons may regulate the neurohypophysis. Nature (Lond.). 277: 653-655.

23. Rossier, J., Q. Pittman, F. Bloom, and R. Guillemin. 1980. Distribution of opioid peptides in the pituitary, a new hypothalamic-pars nervosa enkephalinergic pathway. Fed. Proc. 39: 2555-2560.

24. Reaves, T. A., and J. N. Hayward. 1979. Immunocytochemical identification of enkephalinergic neurons in the hypothalamic magnocellular preoptic nucleus of the goldfish, Carassius auratus. Cell Tissue Res. 200: 147151.

25. Reaves, T. A., and J. N. Hayward. 1979. Intracellular dye-marked enkephalin neurons in the magnocellular preoptic nucleus of the goldfish hypothalamus. Proc. Natl. Acad. Sci. U. S. A. 76: 6009-6011.

26. Miller, M. 1980. Role of endogenous opioids in neurohypophysial function of man. J. Clin. Endocrinol. Metab. 50: 1016-1020.

27. Lightman, S. L., and M. L. Forsling. 1980. Evidence for endogenous opioid control of vasopressin release in man. J. Clin. Endocrinol. Metab. 50: 569-571.

28. Kamoi, K., K. White, and G. L. Robertson. 1979. Opiates elevate the osmotic threshold for vasopressin release in rats. Clin Res. 27: 254a. (Abstr.)

29. Nutt, J. G., and D. R. Jasinski. 1974. Diuretic action of the narcotic antagonist oxilorphan. Clin. Pharmacol. Ther. 15: 361-367.

30. Lightman, S. L., N. Langdon, and M. L. Forsling. 1980. Effects of the opiate antagonist naloxone and the enkephalin analog DAMME on the vasopressin response to a hypertonic stimulus in man. J. Clin. Endocrinol. Metab. 51: 1447-1449.

31. Schrier, R. W., T. Berl, and R. J. Anderson. 1979. Osmotic and nonosmotic control of vasopressin release. Am. J. Physiol. 236: F321-F332.

32. Thrasher, T. N., C. J. Brown, L. C. Keil, and D. J. Ramsay. 1980. Thirst and vasopressin release in the dog: an osmoreceptor or sodium receptor mechanism? Am. J. Physiol. 238: R333-R339.

33. Yagi, K., H. Kannan, and Y. Sawaki. 1980. Electrophysiology of antidiuretic hormone-secreting neurons: afferent neural pathways from cardiovascular receptors. In Antidiuretic Hormone. S. Yoshida, L. Share, and K. Yagi, editors. Japan Scientific Societies Press, Tokyo. 8196.

34. Perry, D. C., K. B. Mullis, S. Oie, and W. Sadee. 1980. Opiate antagonist receptor binding in vivo: evidence for a new receptor binding model. Brain Res. 199: 49-61. 